\title{
LIBERALISASI JASA DISTRIBUSI, MASUKNYA MODAL ASING DAN HUBUNGANNYA DENGAN MODAL DOMESTIK INDONESIA
}

\author{
Muhammad Fawaiq \\ muhammadfawaiq@yahoo.co.id \\ Pusat Pengkajian Kerjasama Perdagangan Internasional, BPPP, Kementerian Perdagangan, RI
}

\begin{abstract}
The aims of this study are to determine the level of liberalization of the services sector and to analyze a causal relationship between Foreign Direct Investment/FDI (as a result of the liberalization of the distribution service) and Domestic Investment/DI in the sector. The method used in this research are descriptive analysis and PanelVECM-Granger. The results showed that the degree of liberalization of distribution services, especially related to FEP has not met the target of liberalization of MEA 2015. Hypothesis testing results show that there is a unidirectional Granger-Causality relationship in short-term and long-term between FDI and DI. That relationship is FDI strongly influencing DI in the Indonesian distribution services sector. ECT value of the independent variable of FDI is -1.0, which means that the speed of change in the value of DI that caused by the changes of FDI to achieve a equilibrium is 100 percent per year. Thus it is known that the entry of FDI encourage domestic investment activity in the Indonesian distribution services sector. The results of this study need to be considered in terms of improvement FEP in the distribution services sector. FEP improvement policy will encourage the entry of FDI and indirectly encourages DI.
\end{abstract}

Key words: liberalization of distribution services sector; FDI; DI: Panel-VECM-Granger.

\section{ABSTRAK}

Tujuan dari penelitian ini adalah untuk mengetahui tingkat liberalisasi sektor jasa distribusi serta menganalisis hubungan kausalitas antara masuknya FDI akibat liberalisasi sektor jasa dengan DI di sektor jasa distribusi. Metode yang digunakan dalam penelitian ini adalah analisis deskriptif dan PanelVECM-Granger. Hasil penelitian menunjukkan bahwa tingkat liberalisasi jasa distribusi khususnya terkait dengan FEP belum memenuhi target liberalisasi MEA 2015. Hasil pengujian hipotesis menunjukkan bahwa terdapat hubungan Kausalitas Granger jangka pendek dan jangka panjang satu arah dimana FDI mendorong DI. Hasil uji kekuatan hubungan kausalitas menunjukkan bahwa FDI secara kuat mendorong aktifitas penanaman modal domestik di sektor jasa distribusi Indonesia. Nilai Koefisien ECT pada variabel bebas FDI sebesar $-1,0$ yang berarti bahwa kecepatan perubahan nilai DI yang disebabkan oleh perubahan nilai FDI untuk mencapai keseimbangan sebesar $100 \%$ per tahun. Dengan demikian diketahui bahwa masuknya FDI mendorong aktifitas penanaman modal domestik di sektor jasa distribusi Indonesia. Hal ini perlu dipertimbangkan dalam hal peningkatan FEP di sektor jasa distribusi. Kebijakan peningkatan FEP ini akan mendorong masuknya FDI dan secara tidak langsung mendorong DI.

Kata kunci: liberalisasi jasa distribusi, FDI, DI, Panel-VECM-Granger.

\section{PENDAHULUAN}

Posisi perdagangan di sektor jasa dalam kerjasama perdagangan internasional sama pentingnya dengan posisi perdagangan di sektor barang. Hal ini berdasarkan pada prinsip single undertaking yang dianut dalam negosiasi kerjasama perdagangan inter- nasional di forum multilateral dibawah World Trade Organiization (WTO). Hal ini juga menjadi acuan pada kerjasama perdagangan yang dilakukan oleh Indonesia terutama dalam bentuk Free Trade Area (FTA) ataupun Economic Partnership Agreement (EPA). Berdasarkan prinsip single under- 
taking, setiap pokok dalam perundingan tidak boleh disepakati hanya sebagian tetapi harus secara menyeluruh (Negrescu dan Truica, 2006). Hal ini juga berarti bahwa kesepakatan FTA atau EPA tidak akan tercapai apabila sektor jasa tidak mencapai suatu kesepakatan. Untuk itu, perdagangan jasa merupakan isu penting yang dinegosiasikan oleh pemerintah Indonesia pada beberapa forum kerjasama internasional seperti forum multilateral dibawa WTO, forum regional dibawa ASEAN dan ASEAN+1 serta kerjasama perdagangan bilateral dibawa Indonesia-Japan Economic Partnership Agreement (IJEPA). Pada kerja sama WTO, perdagangan sektor jasa disepakati sejak putaran Uruguay pada tahun 1994. Kesepakatan tersebut melahirkan suatu kesepakatan di sektor jasa yang disebut dengan General Agreement on Services (GATS). GATS berlaku untuk semua negara anggota WTO dan menjadi acuan penting dalam negosiasi perdagangan yang dilakukan negara-negara anggotanya termasuk Indonesia pada berbagai forum kerjasama perdagangan internasional.

Adapun kerjasama-kerjasama perdagangan jasa antar sesama negara-negara ASEAN dinegosiasikan dalam suatu road map yang disebut dengan ASEAN-Framework Agreement on Services (AFAS). Perundingan AFAS dimulai sejak tahun 1996 (initial Packet) atau AFAS Paket pertama. Sampai saat ini negara-negara ASEAN telah menyepakati AFAS Paket kesembilan. Adapun Indonesia telah meratifikasi AFAS Paket kedelapan dan dalam proses ratifikasi AFAS Paket kesembilan. Dalam kerjasama AFAS, setiap negara diharuskan secara bertahap untuk meliberalisasikan sektor jasanya. Kerjasama-kerjasama perdagangan jasa Indonesia lainnya IJEPA, ASEAN-Korea Free Trade Agreement (AKFTA), ASEAN-Japan Free Trade Agreement (AJFTA), ASEANChina Free Trade Agreement (ACFTA), ASEAN-Australia-New Zealand Free Trade Agreement (AANZFTA), dan ASEAN-India Free Trade Agreement (AIFTA). Selain pada forum kerjasama perdagangan internasional,
Indonesia juga meliberalisasi sektor jasanya secara sepihak melalui Daftar Negatif Investasi (DNI) yang sebelumnya dikenal dengan Daftar Skala Prioritas (DSP).

Selain penting dalam perundingan kerjasama perdagangan internasional, berdasarkan data CIA factbook tahun 2015, sektor jasa juga penting dalam perekonomian negara-negara di dunia termasuk Indonesia yang telah dominan dibandingkan dengan sektor lainnya. Berdasarkan data CIA factbook (2015) tersebut, kontribusi sektor jasa dalam perekonomian Indonesia telah dominan yang mencapai $44,7 \%$ dan lebih tinggi dari sektor industri $(41,3 \%)$ serta sektor pertanian $(14 \%)$. Tingginya peran sektor jasa di Produk Domestik Bruto (PDB) juga terjadi di sebagian besar negara-negara mitra kerjasama perdagangan Indonesia yaitu di ASEAN dan ASEAN+1. Beberapa negara dengan kontribusi sektor jasa di atas $50 \%$ adalah Filipina, Malaysia, Singapura, Thailand, Australia, India, Jepang, Korea Selatan dan Selandia Baru. Di antara negaranegara mitra kerjasama perdagangan Indonesia, hanya Brunei yang kontribusi sektor jasanya lebih rendah dari sektor manufaktur.

Jika dirinci lebih detail dalam PDB Indonesia, jasa yang berkontribusi paling tinggi berdasarkan data BPS tahun 2015 adalah jasa distribusi. Kontribusi sektor jasa ini mencapai $13,44 \%$ dari total PDB. Diurutan kedua dalam kategori sektor jasa adalah sektor jasa konstruksi (9,82\%) dan sektor informasi dan komunikasi sebesar 4,71\% (BPS, 2015). Sektor jasa distribusi juga menempati urutan kedua dari semua sektor dalam hal perannya terhadap PDB Indonesia. Diurutan pertama adalah sektor manufaktur dengan kontribusi sebesar 21,53\% (BPS, 2015).

Posisi penting perdagangan jasa ini dapat dilihat dalam dua sudut pandang. Pertama dari sudut pandang liberalisasi sebagai suatu kewajiban karena keikutsertaan Indonesia dalam berbagai forum kerjasama perdagangan internasional. Kedua, konstribusi sektor jasa yang besar khususnya sektor jasa distribusi dapat 
menggambarkan kepentingan Indonesia untuk melindungi dan mendorong pertumbuhan penyedia sektor jasa domestiknya. Untuk itu, liberalisasi perdagangan jasa khususnya jasa distribusi harus mengutamakan kepentingan nasional Indonesia terutama terkait dengan industri dalam negeri.

Dampak langsung dari liberalisasi perdagangan jasa khususnya terkait dengan liberalisasi batas maksimum kepemilikan modal asing atau foreign equity participation (FEP) adalah masuknya penyedia jasa asing ke Indonesia dalam bentuk foreign direct investment (FDI). Masuknya penyedia jasa asing ke Indonesia akan berdampak pada penyedia jasa domestik Indonesia. Masuknya FDI ke Indonesia dapat berdampak positif dan negatif. Kastrati (2013) meneliti mengenai dampak positif dan negatif FDI bagi negara penerimanya. Beberapa dampak positif masuknya FDI menurut Kastrati (2013) adalah adanya dampak alih suber daya seperti modal, teknologi, dan manajemen, penciptaan lapangan kerja, dampak subtitusi produk impor yang berpengaruh positif pada neraca pembayaran, dampak terhadap peningkatan ekspor. Lebih lanjut Kastrati menyatakan dampak negatif dari FDI adalah persaingan usaha dengan perusahaan-perusahaan domestik.

Untuk mengantisipasi dampak negatif dari liberalisasi atau masuknya pesaing asing tersebut, penelitian ini menguji hubungan Kausalitas Granger antara FDI dengan penanaman modal dalam negeri atau domestic investment (DI). Menurut Ekananda (2016), Kausalitas Granger merupakan kausalitas dalam kerangka statistik bukan dalam kerangka filosofis sehingga konsep ini merujuk pada konsep prediksi. Konsep Kausalitas Granger ini dalam penelitian ini digunakan untuk mengetahui arah hubungan sebab akibat. Hal ini untuk mengetahui dampak FDI bagi DI di Indonesia dan sebaliknya seberapa besar DI mendorong FDI. Hal ini penting sebagai salah satu masukan dalam rangka peningkatan liberalisasi sektor jasa Indonesia khususnya dalam rangka mengikuti cetak bitu Masyarakat Ekonomi ASEAN (MEA) pada tahun 2015. Salah satu tuntutan liberalisasi sektor jasa penting Indonesia adalah tuntutan peningkatan foreign equity participation (FEP) menjadi $70 \%$ sesuai dengan mandat MEA 2015 dan sampai pada tahun 2017 belum dapat terpenuhi. Hal ini akan menjadi tantangan dalam negosiasi perdagangan jasa karena liberalisasi perdagangan pada MEA 2015 masih dipandang belum menguntungkan atau negatif oleh perusahaan-perusahaan domestik di Indonesia.

Berdasarkan pada survey yang dilakukan oleh Chin, Vincent, Michael Meyer, Evelyn Tan, and Bernd Waltermann, (2014), menemukan bahwa perusahaan Indonesia cenderung memandang pemberlakuan MEA 2015 sebagai suatu ancaman, sedangkan perusahaan-perusahaan di Malaysia dan Singapura lebih optimis dan memandang MEA 2015 sebagai suatu peluang (Ridhwan, et al., 2015).

Keterbukaan sektor jasa sebagai bagian dari liberalisasi perdagangan internasional Indonesia adalah sesuatu yang tidak dapat dihindarkan lagi. Hal yang penting dari liberalisasi sektor jasa ini adalah liberalisasi Moda 3 yang terkait dengan investasi. Masuknya investasi ataupun perusahaan asing dapat menjadi pesaing maupun mitra yang mendorong kinerja penyedia jasa domestik. Selain itu masuknya Moda 3 ini juga dapat memberikan manfaat bagi penyerapan tenaga kerja domestik. Penelitian terkait liberalisasi jasa belum banyak dilakukan. Untuk itu, penelitian ini menganalisis mengenai dampak masuknya penyedia jasa asing terhadap penyedia jasa domestik.

\section{TINJAUAN TEORETIS}

Konsep Liberalisasi Perdagangan Jasa di GATS dan Undang-undang Nomor 7 Tahun 2014 Tentang Perdagangan.

Perundingan perdagangan internasional di sektor jasa mengacu kepada General Agreement on Trade in Services (GATS). 
Peraturan perdagangan sektor jasa terutama terkait dengan jenis sektor yang diperdagangkan dan cara jasa diperdagangkan antar negara dalam GATS yang juga diadopsi oleh Undang-undang Nomor 7 Tahun 2014 tentang Perdagangan. Berdasarkan GATS dan Pasal 4 Ayat 2 Undangundang Nomor 7 Tahun 2014, sektor jasajasa yang diperdagangkan dibagi kedalam 12 sektor yaitu (1) jasa bisnis, (2) Jasa komunikasi, (3) jasa konstruksi, (4) jasa distribusi, (5) jasa pendidikan, (6) jasa lingkungan, (7) jasa keuangan, (8) jasa kesehatan dan terkait sosial (9) jasa pariwisata, (10) jasa rekreasi, budaya dan olah raga, (11) jasa transportasi, dan (12) jasa lainnya. Dalam penelitian ini akan mengambil kasus sektor jasa distribusi. Cakupan subsektor-subsektor dalam jasa distribusi berdasarkan dokumen WTO Nomor MTN. GNS/W/120, dibagi kedalam beberapa subsektor seperti jasa keagenan ( jasa grosir, jasa ritel, dan jasa waralaba (WTO, 1991).

Adapun cara perdagangan diatur dalam Pasal 39 Undang-undang Nomor 7 Tahun 2014 sebagai berikut. Pasokan lintas batas (Moda 1) adalah jasa disuplai dari satu negara ke negara lainnya contohnya adalah seorang pasien di Indonesia melakukan konsultasi dengan dokter di Singapura; Konsumsi di luar negeri (Moda 2) adalah jasa disuplai dari saru negara untuk dinikmati oleh konsumen yang datiang dari negara lainnya. Contohnya yaitu konsumen dari negara lainnya seperti wisatawan membeli barang/jasa di ritel atau supermarket Indonesia. Keberadaan komersial (Moda 3) adalah jasa disuplai melalui kehadiran badan usaha suatu negara ke dalam wilayah negara lainnya. Contohnya adalah jaringan supermarket dari Korea Selatan membuat gerainya di Indonesia. Perpindahan manusia (Moda 4) adalah keberadaan tenaga kerja asing atau natural person dari suatu negara di wilayah negara lainnya. Contohnya adalah seorang store manager dari Korea Selatan bekerja di supermarket di Indonesia. Tingkat liberalisasi setiap sektor jasa dituangkan ke dalam suatu dokumen yang disebut dengan
Schedule of Commitment (SOC) seperti yang tunjukkan pada Tabel 3. SOC terdiri dari empat kolom utama: kolom pertama berisi informasi tentang sektor ataupun subsektor jasa yang diliberalisasi, kolom kedua berisi informasi tentang pembatasan akses pasar, kolom ketiga berisi informasi tentang pembatasan perlakuan nasional dan kolom keempat berisi informasi mengenai komitmen tambahan (WTO, 2001). Lebih lanjut WTO (2001) mengenai pedoman pembuatan SOC menguraikan mengenai tingkat liberalisasi sektor jasa yang secara garis besar dibagi menjadi: liberalisasi secara penuh (full liberalization) apabila dalam SOC dituliskan none; kemudian terbuka dengan pembatasan apabila dalam SOC diberikan pembatasanpembatasan termasuk pembatasan jumlah kepemilikan modal asing dan masih ditutup atau tidak terikat dengan perjanjian apabila dalam SOC diberikan kata unbound.

\section{Konsep Liberalisasi Investasi dalam Moda 3 Perdagangan Jasa}

Penelitian ini memadukan teori investasi dalam konteks kerjasama perdagangan internasional di sektor jasa dimana sektor jasa distribusi berdasarkan WTO (2002) merupakan salah satu sektor jasa yang diperjanjikan. Investasi dalam konsep perdagangan jasa ini di bahas dalam perjanjian di Moda 3. Salah satu pokok perjanjian dalam Moda 3 ini adalah mengatur mengenai masuknya penyedia jasa asing dalam hal ini yaitu FDI dari suatu negara ke negara lain. FDI merupakan suatu paket modal, teknologi, manajemen, dan kewirausahaan yang mengijinkan suatu perusahaan untuk beroperasi dan menyediakan barang-barang dan jasa-jasa di pasar luar negeri (Farrell, 2008 dalam Almfraji dan Almsafir, 2013). FDI tidak termasuk investasi portfolio global berbentuk saham lewat jual beli di bursa, obligasi dan surat berharga lainnya (Latip, 2009). Indikasi masuknya penyedia jasa asing ke suatu negara dapat diindikasikan dengan total FDI (Ball, et al., (2012). Dalam kaitan antara liberali- sasi dengan masuknya investasi, Shah dan Khan (2016) menemukan 
bahwa liberalisasi perdagangan secara signifikan mendorong masuknya penanaman modal asing lansung atau FDI.

Salah satu bentuk pembatasan terkait dengan masuknya modal asing atau FDI dalam liberalisasi perdagangan jasa ini adalah pembatasan FEP. Hal ini bertujuan untuk melindungi penyedia jasa domestik terutama yang belum siap untuk bersaing. Namun demikian tidak selamanya Indonesia harus menutup sektor jasanya sementara Indonesia ikut aktif dalam berbagai forum perundingan perdagangan. Untuk saat ini, Indonesia memberikan tingkat liberalisasi tertingginya pada kerjasama ASEAN Framework Agreement on Services (Ishido, 2012). Masih tertutupnya sektor jasa Indonesia menyebabkan tertinggalnya Indonesia dari negara ASEAN lainnya dalam hal daya saing, kontribusi terhadap ekspor, dan rendahnya produktifitas (Findlay dan Pangestu, 2016). Tongson dan Cheong (2016) juga menyarankan agar Indonesia mengurangi hambatan terutama terkait dengan peningkatan batas maksimum kepemilikan modal asing untuk mendorong peningkatan daya saing jasa Indonesia dan mendorong Indonesia dalam global value chain (GVC) melalui investor Korea di Indonesia.

\section{Konsep Masuknya Penyedia jasa atau Modal Asing}

Masuknya penyedia jasa atau perusahaan asing di sektor jasa distribusi tidak terlepas dari liberalisasi perdagangan jasa. Liberalisasi perdagangan jasa akan berpengaruh pada strategi perusahaan untuk masuk ke suatu negara. Moda entri tersebut dibagi menjadi moda entri dengan ekuitas dan moda enteri tanpa ekuitas.

Pendekatan moda entri tanpa ekuitas dapat dilakukan dengan cara mengekspor, proyek turnkey, perijinan, waralaba, kontrak manajemen, dan kontrak manufaktur (Ball, et al., 2012). Pendekatan moda entri yang berbasis pada ekuitas biasanya dalam bentuk kepemilikan modal penuh (wholly owned subsidiary), usaha patungan (joint venture) dan strategi aliansi (strategic allian- ces) (Ball et al., 2012). Terkait dengan ekspansi jasa ritel sebagai bagian dari jasa distribusi, Fawaiq (2015) menemukan bahwa salah satu penyedia jasa ritel dalam hal ini yaitu Alfamart telah berhasil masuk ke pasar jasa ritel Filipina dengan menggunakan pendekatan waralaba karena Filipina masih belum mengijinkan kepemilikan modal asing di negaranya pada saat ekspansi tersebut dilakukan.

\section{Teori Pengaruh Masuknya Modal Asing}

Masuknya FDI ke suatu negara diharapkan dapat bermanfaat bagi negara lainnya terutama dalam hal mendorong GDP, penyerapan tenaga kerja, investasi domestik serta wisatawan manca negara bagi Indonesia. Dalam kaitannya dengan pertumbuhan ekonomi, penelitian Abbes, et al. (2015) menemukan bahwa terdapat hubungan kausalitas satu arah antara FDI dan GDP di Asia, Oceania, Timur Tengah, Amerika Utara, Afrika Utara dan Afrika Tengah dan hubungan kausalitas dua arah di Amerika Latin dan Eropa. Adapun Bayar (2014) menemukan bahwa FDI berpengaruh negatif terhadap pertumbuhan GDP sedangkan investasi domestik berpengaruh positif terhadap pertumbuhan GDP di Turki. Dampak positif masuknya penyedia jasa asing terhadap tenaga kerja telah diteliti oleh Fawaiq (2017). Penelitian Fawaiq (2017) tersebut dilakukan pada sektor jasa telekomunikasi Indonesia dan menemukan bahwa masuknya penyedia jasa telekomunikasi asing yang menanamkan modalnya di Indonesia secara signifikan mendorong penyerapan tenaga kerja di sektor tersebut dan sebaliknya ketersediaan tenaga kerja juga menjadi pertimbangan bagi investor sebelum menanamkan modalnya di Indonesia.

Dalam kaitannya antara FDI dan DI, beberapa peneliti menemukan hubungan antara FDI, DI dan pertumbuhan ekonomi. Shawa, Amoro, dan Yaoshen (2014) menemukan bahwa terdapat hubungan satu arah dimana DI mendorong masuknya FDI ke Kenya. Penelitian Lean dan Tan (2011) 
menemukan bahwa dalam jangka panjang FDI mendorong DI dan dalam jangka pendek DI mendorong masuknya FDI di Malaysia. Ditimi dan Matthew (2014) menemukan bahwa Tidak terdapat hubungan jangka panjang antara FDI dengan DI (investasi swasta dan investasi pemerintah) di Nigeria. Aitken dan Harisson (1999) menemukan bahwa partisipasi modal asing berpengaruh positif pada produktifitas perusahaan-perusahaan kecil dan berpengaruh negatif pada perusahan-perusahaan domestik di Venezuela. Dari keterkaitan antara FDI dan DI di negara-negara tersebut, dengan menggunakan metode penelitian serupa, penelitian ini akan fokus pada hubungan antara FDI dan DI di Indonesia yang secara parsial pada sektor jasa distribusi. Secara umum, hipotesis yang akan di uji dalam penelitian ini adalah:

$\mathrm{H}_{0}$ : Tidak terdapat hubungan Kausalitas Granger antara FDI dan DI.

\section{METODE PENELITIAN}

\section{Analisis Deskriptif}

Analisis deskriptif digunakan untuk menganalisis posisi liberalisasi sektor jasa distribusi Indonesia pada kerjasama perdagangan internasional khususnya di AFAS. Analisis ini juga digunakan untuk menganalisis posisi liberalisasi sektor jasa Indonesia secara unilateral (sepihak) berdasarkan daftar negative investasi Indonesia yang diatur dalam Peraturan Presiden Nomor 44 Tahun 2016 tentang Daftar Bidang Usaha yang Tertutup dan Bidang Usaha yang Terbuka Dengan Persyaratan di Bidang Penanaman Modal.

\section{Pengujian Hipotesis Menggunakan Panel - Vector Error Correction Model (VECM) - Granger.}

Model VECM merupakan pengembangan dari model Vector Autoregresion (VAR) dimana pada Model VECM ini setiap variabel stasioner pada first difference atau turunan pertama dari data (Ekananda 2016). Model VAR itu sendiri mampu menghasilkan model yang merespon adanya

suatu goncangan dalam perekonomian tetapi membiarkanya berjalan sesuai dengan teori dan renpon jangka panjang berdasarkan data historis (Ekananda 2016). Model VAR diubah menjadi model VECM apabila terdapat hubungan jangka panjang atau hubungan kointegrasi antar variabel (Alhayat dan Muslim (2016). Adapun keunggulan dari VECM ini adalah mampu menjelaskan arah hubungan-hubungan jangka panjang antar variabel.

Beberapa penelitian terkait seperti Shawa, et al. (2014), Bayar (2014), serta Lean dan Tan (2011) meng- gunakan metode Vector Error Correction Model (VECM). Adapun penelitian lainnya yaitu Abbes, et al. (2015) serta Ditimi dan Matthew (2014) menggunakan metode serupa yaitu metode Dynamic error correction model (DECM) dan Vector auto regression (VAR). untuk menemukan dampak liberalisasi jasa terutama di Moda 3 secara parsial di sektor lainnya, Fawaiq (2016) juga menggunakan model Panel-VECM untuk mengestimasi dampak masuknya penyedia hotel dan restoran asing pada kedatangan wisatawan mancanegara di Indonesia.

Dengan mempertimbangkan metodemetode pada penelitian sebelumnya, maka metode yang digunakan dalam penelitian ini adalah metode Panel-VECM. Metode ini digunakan untuk mengetahui hubungan kausalitas granger antara kedua variabel. Hubungan kausalitas granger ini dibagi menjadi kausalitas granger jangka pendek, jangka panjang dan gabungan antara keduanya. Persamaan VECM yang digunakan dalam penelitian ini adalah sebagai berikut.

$$
\begin{aligned}
& \Delta \mathrm{FDI}_{\mathrm{i}, \mathrm{t}}=\mathrm{a}_{1, \mathrm{i}}+\varphi_{1, \mathrm{E}} \mathrm{ECT}_{\mathrm{i}, \mathrm{t}-\mathrm{1}}+\sum_{j=1}^{k} \gamma_{1, \mathrm{j}, \mathrm{i}} \Delta \mathrm{FDI}_{\mathrm{i}, \mathrm{t}-\mathrm{j}}+ \\
& \sum_{j=1}^{k} \Theta_{1, \mathrm{j}, \mathrm{i}} \Delta \mathrm{DI}_{\mathrm{i}, \mathrm{t}-\mathrm{j}}+\varepsilon_{1, \mathrm{i}, \mathrm{t}} \ldots \ldots \ldots \ldots \ldots . . .(1) \\
& \Delta \mathrm{DI}_{\mathrm{i}, \mathrm{t}}=\mathrm{a}_{2, \mathrm{i}}+\varphi_{2, \mathrm{i}} \mathrm{ECT}_{\mathrm{i}, \mathrm{t}-\mathrm{i}}+\sum_{j=1}^{k} \gamma_{2, \mathrm{j}, \mathrm{i}} \Delta \mathrm{FDI}_{\mathrm{i}, \mathrm{t}-\mathrm{j}}+ \\
& \sum_{j=1}^{k} \Theta_{2, j, i} \Delta \mathrm{DI}_{\mathrm{i}, \mathrm{t}-\mathrm{j}}+\varepsilon_{2, \mathrm{i}, \mathrm{t}} \\
& \text { Keterangan: } \\
& \text { FDI = foreign direct investment. } \\
& \mathrm{ECT}=\text { lagged error-correction term dari } \\
& \text { hubungan ko-integrasi jangka } \\
& \text { panjang. }
\end{aligned}
$$




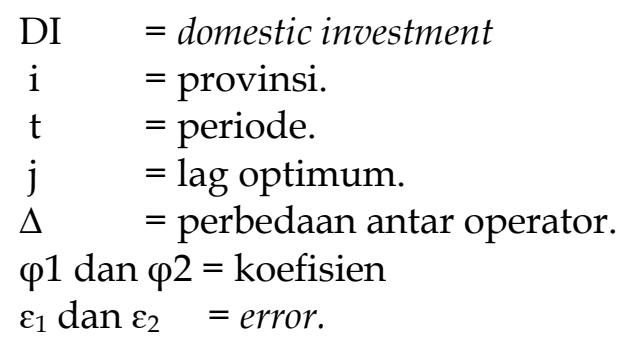

Beberapa tahapan dalam Panel-VECMGranger adalah pengujian stasioneritas, pengujian ko-integrasi, lag length creteria, terakhir adalah pengujian kausalitas PanelVECM-Granger. Pengujian non-stasionaritas menggunakan Im, Pesaran dan Shin (IPS) unit root test. Pengujian pertama dilakukan pada level, apabila data belum stasioner maka akan dilanjutkan pada first differencing. Pengujian tersebut dilakukan pada masingmaing variabel sampai ditemukan ordo yang sama pada keduanya dengan asumsi bahwa kedua variabel (FDI dan DI) terintegrasi pada ordo yang sama. Adapun hipotesis yang diuji pada pengujian non-stasionaritas adalah sebagai berikut.

$\mathrm{H}_{0}$ : probabilitas statistik $>0,05$ atau data mengandung unit root.

Pengujian kointegrasi untuk data panel dalam penelitian ini menggunakan pendekatan yang diusulkan oleh Pedroni (1999). Pengujian ini bertujuan untuk menentukan perlunya kontrol pada hubungan ekuilibrium jangka panjang antar variabel dalam spesifikasi ekonometrika (Samimi, et al., 2013 dalam Fawaiq 2016). Adapun hipotesis yang diuji pada pengujian kointegrasi dengan Pedroni adalah sebagai berikut.

$\mathrm{H}_{0}$ : probabilitas statistik $>0,05$ atau tidak memiliki hubungan kointegrasi.

Selanjutnya pengujian lag yang bertujuan untuk mengukur panjang lag optimum yang digunakan dalam pengujian selanjutnya (Safitriani, 2014). Adapun uji lag dalam penelitian ini diukur menggunakan Schwarz information criterion (SC) dan HannanQuinn information criterion. Setelah proses pengujian-pengujian tersebut, pengujian terakhir adalah pengujian Kasalitas Granger dari Model Panel VECM Granger pada persamaan (1) dan Persamaan (2). Hipotesis yang dikembangkan untuk hubungan kausalitas jangka pendek yaitu:

$\mathrm{H}_{0}: \theta_{1}=0$ pada persamaan (1) yang berarti DI tidak mempengaruhi FDI atau $\gamma_{2}=0$ pada persamaan (2) yang berarti FDI tidak mempengaruhi DI.

Hipotesis untuk pengujian kausalitas Granger jangka panjang adalah sebagai berikut.

$\mathrm{H}_{0}: \varphi_{1}=0$ pada persamaan (1) yang berarti DI tidak mempengaruhi FDI atau $\varphi_{2}=0$ pada persamaan (2) yang berarti FDI tidak mempengaruhi DI.

Untuk menguji kekuatan hubungan antar variabel maka dilakukan pengujian hubungan kausalitas gabungan antara jangka pendek dan jangka panjang. Hipotesis yang akan diuji adalah sebagai berikut.

$\mathrm{H}_{0}: \varphi_{1}=\theta_{1}=0$ pada persamaan (1) yang berarti pengaruh DI pada FDI tidak kuat atau $\varphi_{2}=\gamma_{2}=0$ pada persamaan (2) yang berarti FDI tidak kuat mempengaruhi DI yang berarti FDI kuat berpengaruh pada DI.

Jenis data yang digunakan dalam penelitian ini adalah data kualitatif dan kuantitatif yang bersumber dari sumber sekunder. Data kualitatif yang digunakan untuk mendeskripsikan posisi liberalisasi sektor jasa adalah data Schedule of Commitment (SOC) Indonesia pada kerjasama AFAS Paket 8 yang diperoleh dari ASEAN Sekretariat tahun 2014 dan Data Daftar Negatif Investasi (DNI) dari BKPM.

Data kuantitatif adalah data FDI dan DI yang diperoleh dari Badan Koordinator Penanaman Modal (BKPM). Data yang digunakan dalam penelitian ini adalah data FDI dan DI pada enam provinsi di Indonesia yaitu Sumatra Utara, DKI Jakarta, Jawa Barat, Jawa Tengah, Jawa Timur, dan Provinsi Bali dari tahun 1991-2015. Realisasi investasi domestik atau domestic investment (DI). Realisasi DI pada keenam provinsi tersebut pada periode 1991-2015 rata-rata sebesar $79 \%$ dari total DI nasional di sektor jasa distribusi. Secara nasional nilai penanaman modal domestik di sektor jasa distribusi mencapai $\operatorname{Rp~2,2~triliun~pada~}$ 
tahun 2013 dan terendah sebesar Rp 128 juta di tahun 2000 dengan tren yang positif mencapai 29,77 persen.
Data DI yang digunakan dalam penelitian ini disajikan pada Tabel 1 sebagai berikut.

Tabel 1

Realisasi DI di sektor Jasa Distribusi

\begin{tabular}{rrrrrrrrr}
\hline \hline & Sumut & DKI Jakarta & Jabar & Jateng & Jatim & Bali & Total 6 Provinsi & Total Nasional \\
\hline 1991 & 0 & 28.770 & 0 & 0 & 0 & 0 & 28.770 & 28.770 \\
1992 & 0 & 0 & 0 & 0 & 340 & 0 & 340 & 340 \\
1993 & 0 & 6.381 & 0 & 0 & 0 & 0 & 6.381 & 6.381 \\
1994 & 0 & 62.028 & 0 & 0 & 0 & 585 & 62.613 & 62.613 \\
1995 & 0 & 60.116 & 0 & 0 & 48.600 & 0 & 108.716 & 108.716 \\
1996 & 0 & 12.400 & 0 & 0 & 0 & 0 & 12.400 & 12.400 \\
1997 & 0 & 14.150 & 0 & 0 & 0 & 0 & 14.150 & 23.709 \\
1998 & 9.506 & 3.055 & 12.500 & 0 & 0 & 4.223 & 29.284 & 66.624 \\
1999 & 0 & 109.364 & 0 & 0 & 0 & 0 & 109.364 & 109.364 \\
2000 & 0 & 128 & 0 & 0 & 0 & 0 & 128 & 128 \\
2001 & 0 & 4.429 & 0 & 0 & 195 & 0 & 4.624 & 5.339 \\
2002 & 0 & 83.400 & 0 & 0 & 0 & 0 & 83.400 & 83.400 \\
2003 & 27.204 & 246.411 & 124.206 & 20.910 & 21.411 & 21.375 & 461.517 & 481.168 \\
2004 & 0 & 370.465 & 0 & 0 & 1.400 & 2.500 & 374.365 & 374.365 \\
2005 & 0 & 81.593 & 0 & 0 & 816 & 9.313 & 91.721 & 91.918 \\
2006 & 0 & 345.072 & 297 & 0 & 445 & & 345.814 & 345.814 \\
2007 & 1.000 & 131.837 & 3.000 & 0 & 7.500 & 500 & 143.837 & 144.037 \\
2008 & 50.000 & 526.777 & 0 & 0 & 5.000 & 12.975 & 594.752 & 594.752 \\
2009 & 0 & 50.457 & 36.300 & 0 & 1.305 .048 & 4.000 & 1.395 .805 & 1.440 .919 \\
2010 & 0 & 32.053 & 15.386 & 0 & 0 & 1.572 .927 & 1.620 .367 & 1.620 .377 \\
2011 & 0 & 51.356 & 11 & 0 & 235.507 & 7.302 & 294.175 & 328.594 \\
2012 & 0 & 871.625 & 0 & 0 & 0 & 122 & 871.747 & 1.030 .440 \\
2013 & 701.286 & 428.547 & 93.167 & 255.089 & 149.500 & 154.200 & 1.781 .789 & 2.205 .114 \\
2014 & 0 & 81.971 & 22.550 & 113.074 & 3.004 & 133.650 & 354.249 & 518.458 \\
2015 & 53.500 & 156.214 & 172.502 & 32.019 & 21.137 & 9.662 & 445.034 & 1.426 .602 \\
\hline
\end{tabular}

Sumber: BKPM (2016)

Adapun kontribusi FDI pada keenam provinsi dalam penelitian ini pada periode 1991-2015 rata-rata mencapai $91 \%$ dari total FDI nasional di sektor jasa distribusi Indonesia. Secara nasional, Indonesia pernah mencatat realisasi tertinggi FDI sektor ini yang mencapai USD 710,81 juta dan terendah pada tahun 1991 sebesar USD 2,47 juta Data FDI tersebut disajikan pada Tabel 2 sebagai berikut.

Tabel 2

Realisasi FDI di sektor Jasa Distribusi

\begin{tabular}{rlrrrrrrrr}
\hline \multirow{2}{*}{ Sumut } & \multicolumn{1}{l}{$\begin{array}{l}\text { DKI } \\
\text { Jakarta }\end{array}$} & Jabar & Jateng & Jatim & Bali & \multicolumn{2}{c}{ Total 6 } \\
Provinsi & \multicolumn{1}{c}{$\begin{array}{l}\text { Total } \\
\text { Nasional }\end{array}$} \\
& 0 & 2.170 & 305 & 0 & 0 & 0 & 2.475 & 2.475 \\
\hline 1991 & 0 & 3.3174 & 0 & 0 & 0 & 0 & 33.174 & 34.214 \\
1992 & 0 & 1.500 & 0 & 0 & 0 & 0 & 1.500 & 1.500 \\
1993 & 0 & 17.706 & 572 & 0 & 0 & 0 & 18.278 & 21.078 \\
1994 & & & & & & & & & \\
\hline
\end{tabular}




\begin{tabular}{lrrrrrrrr}
\hline 1995 & 0 & 9.455 & 1.000 & 0 & 0 & 0 & 10.455 & 10.455 \\
1996 & 0 & 6.240 & 0 & 0 & 0 & 0 & 6.240 & 6.670 \\
1997 & 0 & 12.784 & 280 & 0 & 0 & 0 & 13.064 & 14.921 \\
1998 & 0 & 23.642 & 3.020 & 198 & 0 & 0 & 26.860 & 27.282 \\
1999 & 0 & 42.184 & 150 & 0 & 600 & 2708 & 45.642 & 46.543 \\
2000 & 301 & 180.524 & 5.741 & 249 & 1.600 & 2524 & 190.937 & 194.187 \\
2001 & 0 & 55.777 & 6.344 & 186 & 1.277 & 4725 & 68.308 & 69.128 \\
2002 & 500 & 121.054 & 9.157 & 582 & 551 & 2600 & 134.444 & 140.056 \\
2003 & 1.001 & 131.336 & 10.702 & 2.345 & 921 & 368 & 146.672 & 150.578 \\
2004 & 761 & 353.131 & 27.730 & 5.570 & 13.134 & 7332 & 407.659 & 419.727 \\
2005 & 5.368 & 300.474 & 23.913 & 508 & 15.580 & 20411 & 366.255 & 389.096 \\
2006 & 0 & 222.783 & 59.763 & 22.262 & 15.086 & 74894 & 394.789 & 447.469 \\
2007 & 642 & 373.020 & 37.900 & 2.611 & 17.383 & 20568 & 452.123 & 499.638 \\
2008 & 6.547 & 350.179 & 134.134 & 8.841 & 13.731 & 29445 & 542.876 & 582.320 \\
2009 & 74.582 & 484.113 & 67.154 & 5.420 & 16.220 & 14264 & 661.753 & 710.812 \\
2010 & 3.026 & 494.764 & 96.919 & 3.884 & 2.028 & 22388 & 623.007 & 665.395 \\
2011 & 214 & 336.086 & 132.652 & 1.981 & 13.771 & 9272 & 493.976 & 575.545 \\
2012 & 15.083 & 159.926 & 59.189 & 2.445 & 22.118 & 29104 & 287.864 & 368.365 \\
2013 & 14.525 & 348.912 & 59.027 & 4.929 & 33.558 & 39701 & 500.651 & 544.688 \\
2014 & 9.848 & 349.227 & 96.073 & 9.543 & 11.990 & 53019 & 529.700 & 582.379 \\
2015 & 1.541 & 329.794 & 58.622 & 13.146 & 8.017 & 47173 & 458.293 & 536.355 \\
\hline
\end{tabular}

Sumber: BKPM (2016)

\section{ANALISIS DAN PEMBAHASAN Liberalisasi Sektor Jasa Distribusi Indo- nesia}

Pada kerjasama AFAS terbaru yang telah disahkan oleh Indonesia yaitu AFAS Paket 8, Indonesia membuka 3 (tiga) subsektor di sektor jasa distribusi. Ketiga subsektor jasa distribusi tersebut yaitu jasa grosir yang hanya diperbolehkan menjual makanan, minuman dan tembakau, serta jasa grosir yang hanya diperbolehkan menjual tekstil, pakaian dan alas kaki serta multi level marketing. Adapun untuk jasa grosir, berdasarkan SOC Indonesia, jasa grosir asing yang membuka gerainya di Indonesia hanya diijinkan untuk memiliki luas area penjualan lebih besar dari 5000 meter persegi. Adapun batas maksimum kepemilikan modal asing yang diijinkan pada sektor jasa distribusi Indonesia pada perjanjian AFAS Paket 8 tersebut adalah maksimum 51\%. Hal ini berarti bahwa penyedia jasa distribusi asing dijinkan untuk memiliki saham mayoritas serta melakukan control pada perusahaan jasa distribusi yang dimilikinya di Indonesia. Selain pembatasan akses pasar, Indonesia juga memberikan pembatasan perlakuan nasional dimana pembatasan ini juga berlaku bagi penyedia jasa domestik. Pembatasan perlakuan nasional yang diberikan Indonesia adalah adanya kewajiban bagi penyedia jasa asing yang masuk ke Indonesia untuk bekerjasama dengan minimal 100 usaha kecil dan menengah.

Selanjutya, penyedia jasa asing hanya diperbolehkan untuk beroperasi di pulau Kalimantan, Sulawei, Nusa Tenggara, Maluku dan Papua serta diharuskan untuk berlokasi di daerah suburban pada setiap ibu kota provinsi di daerah-daerah tersebut. Hal ini bertujuan untuk mendorong perkembangan jasa distribusi di daerah-daerah tersebut. Hal ini karena kurangnya aktifitas usaha dan penanaman modal di provinsiprovinsi tersebut. Adapun SOC Indonesia pada AFAS 8 disajikan pada Tabel1 sebagai berikut. 
Tabel 3

SOC Indonesia di Jasa Distribusi pada Kerjasama AFAS Paket 8

INDONESIA -SCHEDULE OF SPECIFIC COMMITMENTS

For the $8^{\text {th }}$ Package of Commitments under ASEAN Framework Agreement on Services

$\begin{array}{llll}\text { Modes of Supply: } & \text { 1) Cross-border supply 2) Consumption aboard 3) Commercial presence } & \text { 4) Presence of natural persons }\end{array}$

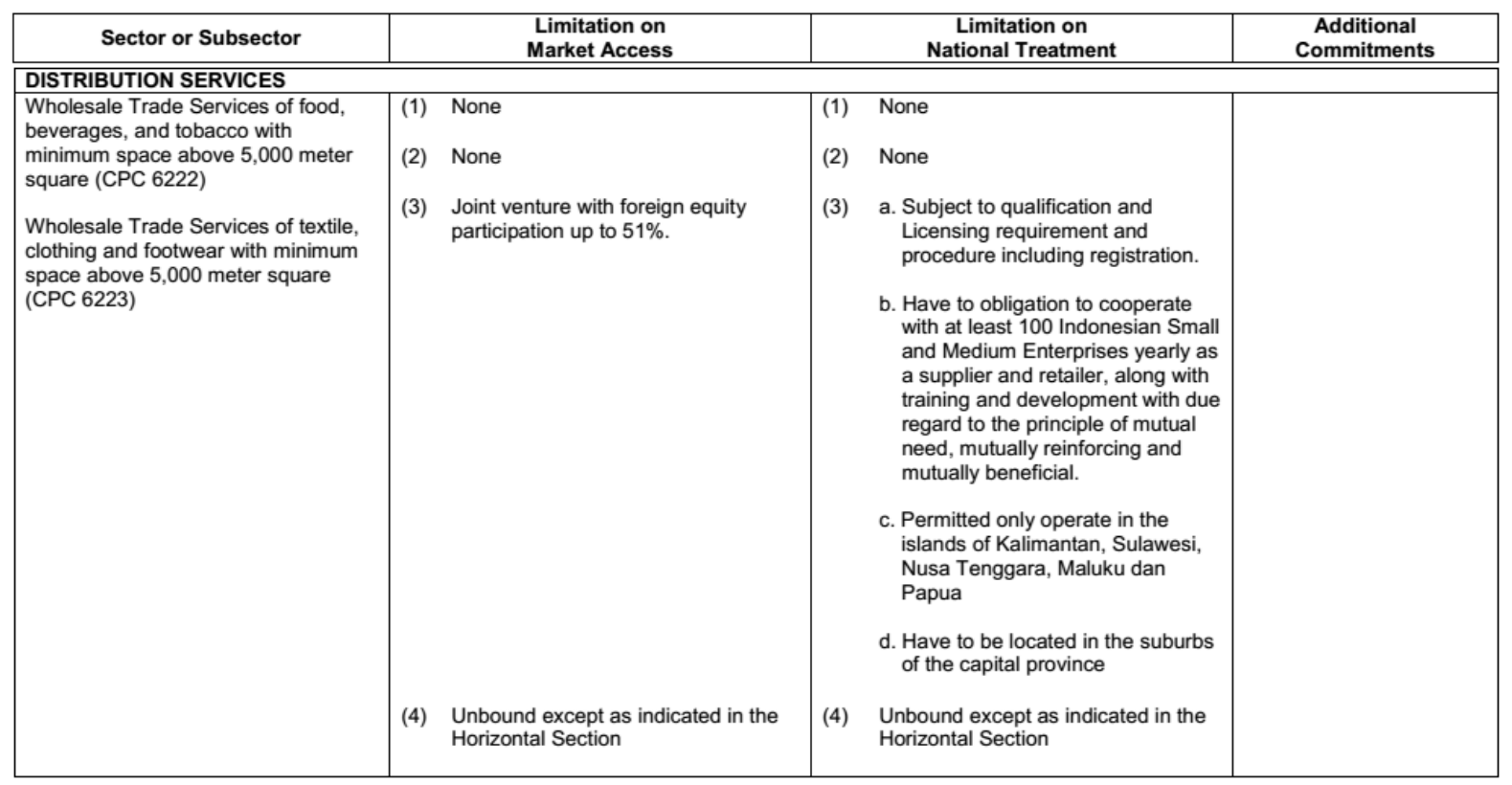

Sumber: ASEAN Secretariat (2014).

Berdasarkan Tabel 3, Indonesia telah membuka Moda 1 (perdagangan lintas batas) dan Moda 2 (konsumsi di luar negeri) dengan tingkat liberalisasi penuh atau tanpa pembatasan. Hal ini berarti bahwa perdagangan jasa lintas batas di sektor jasa distibusi tidak dibatasi. Selain itu, konsumen dari luar negeri yang akan menikmati jasa distribusi Indonesia juga tidak dibatasi. Adapun fokus liberalisasi yang dilakukan Indonesia di sektor jasa distribusi adalah pada Moda 3 (kehadiran komersial). Liberalisasi penting di Moda 3 ini adalah batas maksimum kepemilikan modal asing. Adapun Moda 4 atau perpindahan manusia atau masuknya pekerja asing di sektor jasa distribusi masih ditutup. Hal ini bertujuan untuk melindungi tenaga kerja sektor jasa konstruksi Indonesia.

Dari segi batas kepemilikan modal asing, tingkat liberalisasi yang diberikan Indonesia termasuk tinggi karena telah mengijinkan kepemilikan modal mayoritas bagi asing. Namun demikian, pembatasan- pembatasan seperti batas luas lantai serta batasan wilayah-wilayah Indonesia tertentu yang dibuka merupakan suatu restriksi bagi penyedia jasa asing untuk masuk ke pasar jasa Indonesia. Lebih lanjut pada peraturan domestik Indonesia terkait dengan daftar negatif investasi (DNI) di sektor jasa distribusi, Indonesia telah mengijinkan kepemilikan modal asing sampai dengan 67\% (Perpres Nomor 46, 2016). Batas maksimum kepemilikan modal asing yang diberikan pada DNI Indonesia telah lebih besar dari AFAS Paket 8. Hal ini juga disebut dengan policy space yang bertujuan untuk memberikan fleksibilitas dalam perundingan. Namun dalam pelaksanaanya, tidak menutup kemungkinan bahwa penyedia jasa asing masuk melalui regulasi domestik.

\section{Realisasi DI dan FDI di sektor jasa} distribusi Indonesia

Provinsi dengan rata-rata realisasi DI tertinggi dari tahun 1991-2015 adalah Provinsi DKI. Jakarta. Realisasi DI di Provinsi 
DKI. Jakarta ini rata-rata sebesar Rp 150,34 milyar per tahun. Di posisi kedua adalah Provinsi Bali dengan realisasi DI rata-rata dalam periode tersebut sebesar $\mathrm{Rp}$ 80,56 milyar per tahun, dan diurutan ketiga adalah Provinsi Jawa Timur dengan rata-rata DI sebesar Rp 71,99 milyar. Adapun realisasi DI di Provinsi Sumatra Utara berada di urutan keempat yaitu sebesar Rp 33,70 milyar, selanjutnya adalah Provinsi Jawa Tengah sebesar RP 16,84 milyar per tahun dan Provinsi Jawa Barat sebesar Rp 19,19 milyar per tahun. Jika kontribusi khusus untuk Pulau Jawa, total kontrbusi DI di pulai ini dalam periode tersebut mencapai $55 \%$. Adapun Provinsi Bali merupakan provinsi diluar jawa dengan kontribusi terbesar yang mencapai $17 \%$ kemudian Provinsi Sumatra Utara sebesar $7 \%$.

Tren penanaman modal domestik (DI) di sektor jasa distribusi pada keenam provinsi ini adalah sebesar 28, 37 persen. Tren tersebut lebih rendah dari rata-rata nasional. Hal ini disebabkan karena mulai tingginya aktifitas DI terutama setelah tahun 2000. Sebelumnya pada periode 1991 sampai 1999, aktifitas penanaman modal domestik hanya terpusat di Provinsi DKI. Jakarta. Adapun kontribusi realisasi DI rata-rata pada periode 1991-2015 pada enam provinsi di Indonesia disajikan pada Gambar 1 sebagai berikut.

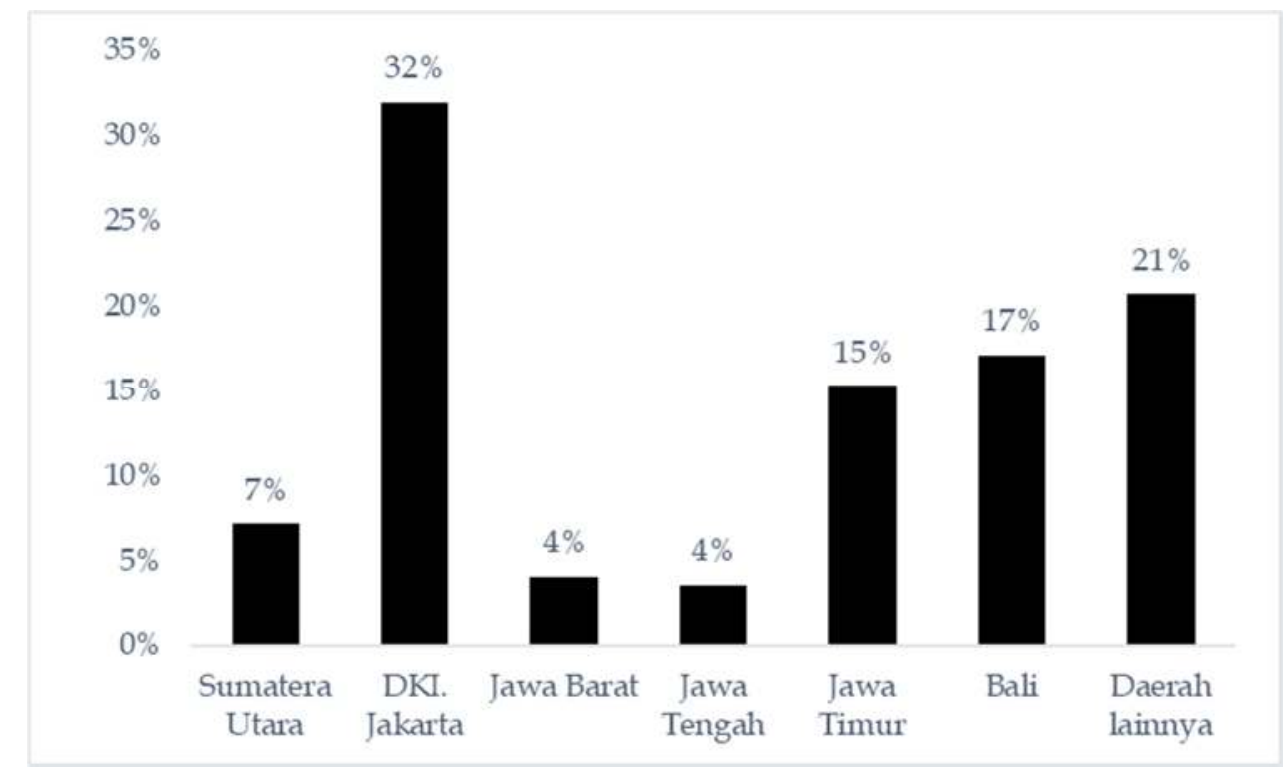

\section{Gambar 1 \\ Kontribusi Realisasi DI rata-rata per tahun di Indonesia periode 1991-2015 Sumber: data diolah}

Adapun realisasi FDI rata-rata per tahun di sektor jasa distribusi dalam periode 19912015 sebagian besar (67\%) berada di Provinsi DKI Jakarta. Selain itu, Provinsi DKI. Jakarta selalu menerima FDI di sektor jasa distribusi setiap tahun dalam periode tersebut. Realisasi FDI di Provinsi DKI.

Jakarta adalah sebesar USD 189.6 juta per tahun. Provinsi Jawa Barat berada di urutan kedua dengan rata-rata FDI di sektor jasa distribusi sebesar USD 35,2 juta per tahun. Dalam periode 1991-2015 (kecuali tahun 1992, 1993 dan 1992), Provinsi Jawa Barat juga selalu mendapatkan FDI sejak tahun 1997 di sektor ini. Adapun Provinsi Bali diurutan ketiga dengan rata-rata FDI sebesar USD 15,2 juta per tahun. Kontribusi realisasi FDI di sektor jasa distribusi rata-rata per tahun periode 1991-2015 disajikan pada pada Gambar 3. 


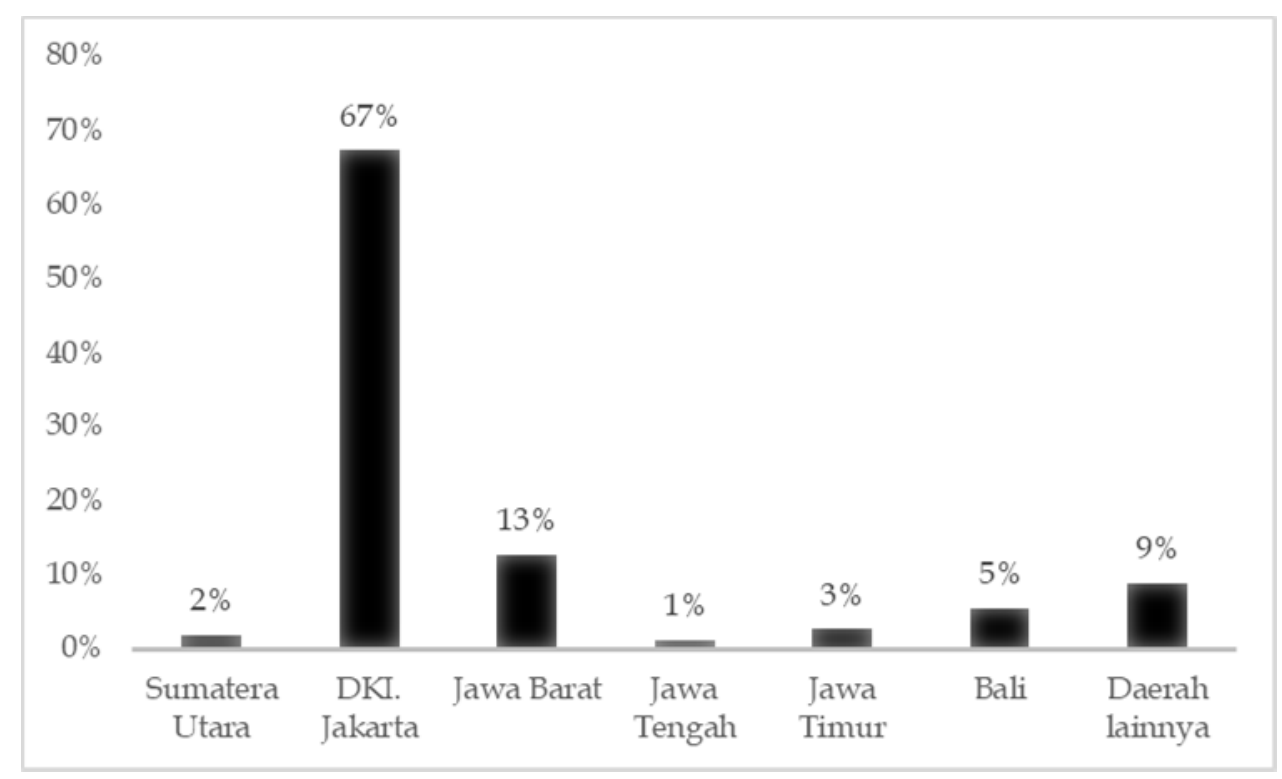

Gambar 2

Kontribusi Realisasi FDI rata-rata per tahun di Indonesia periode 1991-2015 Sumber: data diolah

Sebagaimana yang ditunjukkan pada Gambar 2, terdapat perbedaan yang cukup signifikan antara DKI. Jakarta dan Jawa Barat dengan Provinsi Lainnya. Hal ini disebabkan karena kedekatan antara Jawa Barat dengan DKI. Jakarta. Untuk daerah luar Pulau Jawa, Provinsi Bali juga merupakan daerah tertinggi dalam hal kontribusi FDI-nya. Adapun kontribusi daerah luar Pulau Jawa lainnya yaitu Sumatra Utama yang berkontribusi sebesar $2 \%$ dari total nasional.

Realisasi FDI dan DI pada sektor jasa distribusi Indonesia masih terpusat pada keenam provinsi pada penelitian ini. Adapun 28 provinsi-provinsi lainnya hanya berkontribusi sebesar 21 persen untuk realisasi DI dan 9 persen untuk realisasi FDI. jika digabungkan, kontribusi FDI di Provinsi DKI. Jakarta dan Provinsi Jawa Barat telah mencapai 80 persen dari total realisasi FDI di sektor jasa distribusi nasional. Untuk itu dalam kerjasama perdagangan internasional di sektor jasa sebagaimana ditunjukan pada Gambar 2, Indonesia secara khusus mengijinkan masuknya modal asing atau FDI terutama pada daerah-daerah di luar pulau jawa. Hal ini bertujuan untuk mendorong pertumbuhan jasa distribusi di wilayah timur Indonesia.

\section{Hubungan Kausalitas FDI dan DI di Sektor Jasa Distribusi}

Sesuai dengan tahapan dalam pengujian Kausalitas Granger dengan Panel-VECM, langkah pertama yang dilakukan adalah pengujian stasioneritas. Pengujian ini bertujuan untuk memperoleh ordo yang sama pada setiap variabel sehingga hasil estimasi menjadi akurat. Hasil pengujian stasioneritas menggunakan pendekatan Im, Pesaran and Shin W-stat (IPS) disajikan pada Tabel 4 sebagai berikut. Berdasarkan Tabel 4, nilai probalitas W-statistik untuk variabel DI pada ordo level lebih kecil dari taraf $5 \%$ yang berarti menolak hipotesis $\mathrm{H}_{0}$ atau variabel DI telah stasioner pada level.

Adapun nilai probalitas W-statistik pada level untuk variabel FDI lebih besar dari taraf 5\%. Dengan demikian, hasil pengujian hipotesisnya adalah menolak $\mathrm{H}_{0}$ atau variabel FDI masih mengandung unit root (belum stasioner). Dengan prinsip kesamaan ordo dalam pemodelan, maka pengujian stasioner dilanjutkan ke ordo selanjutnya yaitu first difference (turunan pertama). 
Tabel 4

Pengujian Stasioneritas

\begin{tabular}{lll}
\hline Variabel & W-Stat (Prob) pada Level & $\begin{array}{l}\text { W-Stat (Prob) pada First } \\
\text { Difference }\end{array}$ \\
\hline DI & $-3.07370(0.0011)^{*}$ & $-9.04228(0.0000)^{*}$ \\
FDI & $-0.32534(0.3725)$ & $-8.18052(0.0000)^{*}$ \\
\hline
\end{tabular}

Ket. *) Signifikan pada taraf 5\%.

Sumber: data diolah

Hasil pengujian pada ordo first difference menunjukkan bahwa nilai probalitas Wstatistik untuk kedua variabel (FDI dan DI) telah lebih kecil dari taraf 5\% atau kedua variabel tidak lagi mengandung unit root atau menolak $\mathrm{H}_{0}$ dengan kata lain data telah stasioner. Ordo firs difference (D) akan digunakan pada persamaan (1) dan persamaan (2). Selain itu, estimasi model VECM juga mengharuskan agar setiap variabel stasioner di ordo turunan pertama ini. Setelah diperoleh ordo pada pengujian stasioneritas, maka dilakukan pengujian selanjutnya yaitu pengujian hubungan kointegrasi. Pengujian ini bertujuan untuk mengetahui hubungan jangka panjang antara variabel FDI dengan variabel DI. Pengujian ini juga menentukan apakah estimasi dilanjutkan menggunakan model VECM atau model VAR. Apabila kedua variabel memiliki hubungan kointegrasi maka estimasi dilanjutkan menggunakan model VECM dan apabila tidak memiliki hubungan jangka panjang (kointe grasi) maka pengujian dilanjutkan menggunakan model Vector auto regression (VAR) (Hill. Griffiths dan Lim, 2012). Adapun hasil pengujian kointegrasi disajikan pada Tabel 4 sebagai berikut.

Tabel 5

Hasil Pengujian Pedroni Panel Ko-integrasi

\begin{tabular}{lcc}
\hline \hline \multicolumn{1}{c}{ Test Statistics } & Statistic & Prob \\
\hline Panel v-Statistic & 1.340770 & 0.0900 \\
Panel rho-Statistic & -7.639909 & 0.0000 \\
Panel PP-Statistic & -8.220109 & 0.0000 \\
Panel ADF-Statistic & -7.913234 & 0.0000 \\
Group rho-Statistic & -6.107689 & 0.0000 \\
Group PP-Statistic & -7.915313 & 0.0000 \\
Group ADF-Statistic & -2.757345 & 0.0029 \\
\hline
\end{tabular}

Sumber: data diolah

Hasil pengujian kointegrasi dengan Pedroni pada Tabel 5 menunjukkan bahwa nilai probabilitas statistik pada setiap parameter adalah lebih rendah dari taraf $5 \%$. Keputusunan dari pengujian Hipotesisnya adalah menolak $\mathrm{H}_{0}$. Hal ini berarti bahwa kedua variabel memiliki hubungan koointegrasi atau hubungan jangka panjang. Adanya hubungan jangka penjang inilah yang menjadi landasan penting dalam pengujian selanjutnya. Oleh karena hubu- ngan kointegrasi hanya menentukan ada atau tidak hubungan jangka panjang antar variabel dan belum menunjukkan arah hubungan sebab akibat masing-masing variabel.

Selanjutnya, perlu dilakukan pengujian kausalitas dengan model Panel-VECMGranger. Sebelum melakukan pengujian tersebut, terlebih dahulu melakukan uji panjang lag. Adapun hasil pengujian panjang lag disajikan pada Tabel 6 sebagai berikut. 
Tabel 5

Hasil Pengujian Panjang Lag

\begin{tabular}{lcc}
\hline Lag & Schwarz information criterion & Hannan-Quinn information criterion \\
\hline 0 & 53.38670 & 53.35422 \\
1 & $51.85105^{*}$ & $51.75363^{*}$ \\
2 & 51.91764 & 51.75527 \\
3 & 52.03344 & 51.80613 \\
4 & 52.16585 & 51.87359 \\
5 & 52.33771 & 51.98051 \\
\hline
\end{tabular}

Ket: varibel berpengaruh pada tanda $\left(^{*}\right)$ Sumber: data diolah

Pengujian panjang lag pada Tabel 6 menunjukkan bahwa kedua variabel berhubungan pada lag pertama. Hubungan antar variabel pada lag pertama menunjukkan bahwa perubahan nilai variabel DI disebabkan oleh perubahan nilai variabel FDI pada satu tahun sebelumnya dan juga sebaliknya, perubahan nilai variabel FDI disebabkan oleh perubahan nilai variabel DI pada satu tahun sebelumnya. Setelah serangkaian pengujian sebelumnya (uji stasioneritas, uji kointegrasi dan uji panjang lag), maka pengujian Kausalitas Granger dengan estimasi Panel-VECM-Granger akan menggunakan ordo pada first difference (D) dan pada lag pertama (-1). Adapun hasil pengujian koefisien $\theta 1$ dan $\gamma 2$ untuk hubungan Kausalitas Granger jangka pendek dengan Wald Test disajikan pada Tabel 7 sebagai berikut.

Tabel 7

Pengujian Wald untuk Hubungan Kausalitas Granger Jangka Pendek

\begin{tabular}{llll}
\hline Koefisien & F-statisitik & Prob. & Keterangan \\
\hline$\Theta_{1}$ & 0.931142 & 0.3365 & ${\text { Menerima } \mathrm{H}_{0}}$ \\
$\gamma_{2}$ & 10.07344 & 0.0019 & ${\text { Menolak } \mathrm{H}_{0}(\mathrm{FDI} \rightarrow \mathrm{DI})}^{\text {Sumber: data diolah }}$ \\
\end{tabular}

Pengujian hubungan jangka pendek pada Tabel 7 menunjukkan bahwa terdapat hubungan satu arah antara FDI dengan DI. Nilai probabilitas F-statistik pada koefisien $\Theta_{1}$ lebih kecil dari 5\% sehingga keputusan dalam pengujian hipotesisnya adalah menolak hipotesis $\mathrm{H}_{0}$. Adapun nilai probabilitas F-statistik pada koefisien $\gamma_{2}$ lebih besar dari $5 \%$ atau menerima hipotesis $\mathrm{H}_{0}$. Dengan demikian, hubungan jangka pendek satu arah kedua variabel tersebut adalah masuknya FDI di sektor jasa distribusi signifikan mendorong investor domestik untuk ikut menanamkan modalnya pada sektor jasa distribusi dalam jangka pendek pada tingkat kepercayaan 95\%. Hal ini tidak berlaku sebaliknya dimana aktifitas DI di sektor jasa distribusi tidak mendorong masuknya FDI di sektor yang sama. Setelah hubungan Kausalitas Granger jangka pendek diketahui, selanjutnya, di lakukan pengujian Kausalitas Granger jangka panjang.

Adapun hasil pengujian hubungan Kausalitas Granger jangka pan jangdisajikan pada Tabel 8 sebagai berikut. Nilai probabilitas koefisien ECT pada variabel bebas DI $\left(\varphi_{1}\right)$ sebagaimana yang ditunjukkan Tabel 6 lebih besar daripada taraf 5 persen. Hal ini menunjukkan bahwa hasil pengujian hipotesis adalah menolak hipotesis nol $\left(\mathrm{H}_{0}\right)$ atau variabel FDI tidak dipengaruhi oleh variabel DI pada tingkat kepercayaan 95\%. 
Tabel 8

Pengujian Wald untuk Hubungan Kausalitas Granger Jangka Panjang

\begin{tabular}{llll}
\hline \hline Koefisien ECT & F-statisitik & Prob. & Keterangan \\
\hline$\varphi_{1}(0,0)$ & 10.07344 & 0.34 & Menerima $\mathrm{H}_{0}$ \\
$\varphi_{2}(-1,0)$ & 4.092260 & 0.04 & Menolak $\mathrm{H}_{0}(\mathrm{DI} \rightarrow$ FDI $)$ \\
\hline
\end{tabular}

Sumber: data diolah

Sebaliknya, nilai probabilitas koefisien ECT pada variabel bebas FDI $\left(\varphi_{2}\right)$ lebih kecil dari taraf 5 persen. Hasil pengujian hipotesis tersebut adalah menolak hipotesis nol $\left(\mathrm{H}_{0}\right)$ atau variabel DI secara signifikan dipengaruhi oleh variabel FDI pada tingkat kepercayaan 95\%. Dengan demikian, diketahui bahwa kedua variabel (DI dan FDI) memiliki hubungan Kausalitas Granger satu arah. Dengan kata lain, aktifitas penanaman modal domestik di sektor jasa distribusi Indonesia dipengaruhi masuknya FDI disektor jasa tersebut dalam jangka panjang. Hal ini tidak berlaku sebaliknya, dimana realisasi aktifitas penanaman modal domestik tidak signifikan mendorong masuknya penanaman modal asing langsung. Hasil ini berbeda dengan hasil penelitian Ditimi dan Mattew (2014) yang menemukan bahwa tidak terdapat hubungan Kausalitas Granger jangka panjang antara FDI dan DI. Dengan kata lain, menurut Matew (2014) FDI tidak mendorong DI dan sebaliknya DI tidak mendorong FDI. Adapun nilai koefisien ECT pada variabel bebas DI sebesar $-1,0$ yang berarti bahwa kecepatan perubahan nilai variabel DI yang disebabkan oleh perubahan nilai variabel FDI untuk mencapai keseimbangan jangka panjang sebesar $100 \%$ per tahun. Hal ini menunjukkan bahwa kecepatan perubahan nilai variabel DI untuk mencapai keseimbangan akibat perubahan nilai FDI untuk menuju keseimbangan jangka panjang adalah mencapai dua kali lipat.

Untuk menguji kekuatan hubungan Kausalitas Granger antara kedua variabel maka dilakukan gabungan pengujian jangka panjang dan jangka pendek. Adapun koefisien yang diuji yaitu seperti yang ditunjukkan pada Tabel 9 sebagai berikut.

Tabel 8

Hasil Wald Test pada Panel Kausalitas Gabungan antara Jangka Pendek dan Jangka Panjang

\begin{tabular}{lll}
\hline \hline Variabel Terikat & $\Delta$ DI ECT(-1) & $\Delta$ FDI ECT(-1) \\
\hline FDI & $2.820513(0,0634)$ & \\
DI & & $4.092260(0,0452)$ \\
\hline
\end{tabular}

Sumber: data diolah

Keterangan: semua nilai dalam tabel adalah F-statistik.

Nilai probabilitas F-statistik pada pengujian gabungan antara kausalitas jangka pendek dan jangka panjang pada Tabel 9 adalah lebih besar dari taraf 5\% untuk variabel terikat FDI. Hal ini berarti bahwa realisasi penanaman modal domestik (DI) tidak secara kuat dan siginifikan mendorong masuknya FDI.

Hal ini berlaku sebaliknya pada variabel bebas FDI dimana nilai probabilitas Fstatistiknya lebih kecil dari 5\% yang berarti bahwa realisasi FDI secara kuat mendorong penanaman modal domesatik (DI) pada tingkat kepercayaan 95\%. Hasil pengujian kekuatan hubungan Kausalitas Granger antara kedua variabel ini sesuai dengan hasil penelitian Lea dan Tan (2011) yang menemukan bahwa realisasi FDI mendorong aktifitas penanaman modal dalam negeri di Kenya. Secara ringkas hasil penelitian ini dapat diilustrasikan pada Gambar 3 sebagai berikut. 


\begin{tabular}{|l|}
\hline Penyedia jasa \\
distribusi asing \\
datang ke \\
Indonesia \\
membawa FDI \\
\hline
\end{tabular}

\section{Gambar 3 \\ Hubungan antara Kausalitas Granger FDI dan DI disektor jasa distribusi Indonesia}

Hasil pengujian kuatnya pengaruh FDI terhadap DI juga mengindikasikan bahwa adanya pengaruh positif dan kuat dari masuknya penyedia jasa asing di sektor jasa distribusi melalui penanaman modal asing langsung yang mampu mendorong tumbuhnya kegiatan usaha domestik. Beberapa dampak positif masuknya penyedia jasa asing melalui FDI telah dijabarkan sebelumnya oleh Kastrati (2013) yaitu adanya alih sumber daya alih modal, alih teknologi dan alih manajemen ke penyedia jasa domestik. Adapun dampak negatif yang juga dijelaskan oleh Kastrati (2013) yaitu terjadi persaingan dimana masuknya FDI menekan atau mengancam DI tidak ditemukan dalam penelitian ini.

Salah satu contoh dari masuknya penyedia jasa distribusi yang berpengaruh positif pada penyedia jasa domestik adalah pada penyedia jasa Carrefour. Carrefour yang merupakan perusahaan supermarket yang berasal dari Perancis mulai berekspansi ke Indonesia sejak tahun 1996 kemudian menjadi PT. Carrefour Indonesia pada tahun 2008 (DetikFinance, 2012). Pada tahun 2011, $100 \%$ saham perusahaan ini diakuisisi oleh perusahaan domestik Indonesia yang bernama PT Trans Ritel (DetikFinance, 2012). Menurut CEO CT Corp yang merupakan induk dari PT Trans Ritel, dengan akuisisi $100 \%$ tersebut, maka perusahaan asal perancis tersebut akan menjadi $100 \%$ lokal (Berita Satu, 2012). Lebih lanjut menurut Berita Satu (2012) tersebut, dalam lima tahun setelah akuisisi, PT Trans Ritel masih diperbolehkan menggunakan nama Carrefour. Dari kasus akusisi ini maka dapat diketahui bahwa masuknya penyedia jasa asing dengan system dan manajemen yang baik akan mendorong perusahaan lokal untuk masuk ke pasar ini. Dengan masuknya perusahaan lokal maka dapat terjadi pengalihan teknologi dan manajemen sehingga ke depan penyedia jasa distribusi Indonesia dapat berekspansi ke luar negeri.

\section{SIMPULAN}

Posisi liberalisasi Indonesia khususnya pada fora AFAS Paket 8 masih berada di bawah target MEA tahun 2015. Batas maksimum kepemilikan modal asing yang diamanatkan oleh MEA masih belum tercapai. Namun demikian DNI Tahun 2016 telah lebih liberal daripada hasil perundingan AFAS Paket 8 tersebut. Dengan demikian dimungkinkan peningkatan posisi liberalisiasi sektor jasa distribusi di Moda 3 dari sudut pandang regulasi domestik Indonesia. Kontribusi penanaman modal dalam negeri atau domestic investment (DI) di sektor jasa distribusi pada enam provinsi dalam penelitian telah mewakili total Indonesia disektor jasa ini.

Hal yang sama juga ditunjukkan oleh kontribusi realisasi FDI sektor jasa distribusi. Provinsi DKI Jakarta merupakan provinsi dengan kontribusi terbesar untuk DI dan maupun FDI. Hal ini menunjukkan bahwa konsentrasi realisasi DI di Indonesia telah menyebar dibeberapa wilayah Indonesia khusunya di enam provinsi ini tetapi konsentrasi FDI masih terpusat di Provinsi DKI. Jakarta dan belum merata di semua provinsi terutama di propinsi-propinsi yang berada di wilayah timur Indonesia. 
Kebijakan liberalisasi sektor jasa distribusi Indonesia di AFAS yang hanya mengijinkan masuknya penyedia jasa asing di wilayah timur Indonesia telah tepat.

Hubungan kausalitas kedua variabel (FDI dan DI) diuji menggunakan PanelVECM-Granger dengan beberapa tahap pengujian seperti uji stasioneritas, uji kointegrasi, dan uji panjang lag. Berdasarkan hasil pengujian stasioneritas diketahui bahwa kedua variabel (FDI dan DI) memiliki ordo yang sama pada first difference. Hasil pengujian kointegrasi menunjukkan bahwa kedua variabel memiliki hubungan kointegrasi atau hubungan jangka panjang. Hasil uji panjang lag menunjukkan bahwa kedua variabel saling berhubungan pada lag pertama. Setelah melewati pengujian-pengujian tersebut kemudian dilakukan pengujian hubungan kausalitas dengan VECM Granger. Hasil pengujian Kausalitas Granger menunjukkan bahwa terdapat hubungan Kausalitas Granger jangka pendek satu arah di mana realisasi FDI sektor jasa distribusi mendorong DI di sektor jasa tersebut. Dengan demikian $\mathrm{H}_{0}$ yang menyatakan bahwa tidak terdapat hubungan Kausalitas Granger antara FDI dan DI ditolak.

Adapun hasil pengujian hubungan Kausalitas Granger jangka panjang menunjukkan bahwa kedua variavel memiliki hubungan Kausalitas Granger satu arah. Hubungan tersebut adalah masuknya FDI mendorong aktivitas DI di sektor jasa distribusi Indonesia. Perubahan nilai DI yang disebabkan oleh perubahan nilai FDI sebagaimana yang ditunjukkan oleh nilai ECT yang mendekati dua kali lipat dalam setahun. Kekuatan Kausalitas Granger ini diuji lagi dengan menggabungkan antara Kausalitas Granger jangka pendek dan Kausalitas Granger jangka panjang. Hasil pengujian kekutan hubungan antara kedua variabel juga signifikan satu arah dimana FDI secara kuat mendorong DI.

\section{SARAN}

Melihat signifikan dan kuatnya hubungan kausalitas antar kedua variabel dimana
FDI di sektor jasa distribusi mendorong aktifitas penanaman modal domestik di sektor jasa distribusi Indonesia. Hal ini juga berarti bahwa masuknya modal asing melalui FDI tidak mengganggu aktifitas usaha domestik yang tetapi mendorong aktifitas penyedia jasa domestik (DI). Adanya keraguan mengenai dampak negative FDI tehadap DI atau masuknya peneydia jasa asing akan menimbulkan persaingan yang menyebabkan tekanan pada penyedia jaasa domestik tidak terbukti pada penelitian ini. Salah satu pertimbangan dalam membuka sektor jasa distribusi terutama terkait dengan Moda 3 adalah untuk melindungi penyedia jasa dalam negeri dan bermanfaat bagi penyedia jasa.

Dengan demikian hasil penelitian ini dapat dijadikan bahan pertimbangan dalam peningkatan liberalisasi di AFAS. Untuk mencapai tingkat liberalisasi kepemilikan modal asing sebagaimana yang diatur dalam Moda 3 kerjasama perdagangan jasa sebagaimana amanat dari MEA 2015 belum dapat dipenuhi oleh Indonesia. Namun demikian, dengan mempertimbang hasil penelitian ini dan regulasi domestik di sektor jasa distribusi maka dapat diusulkan peningkatan persentasi kepemilikan modal asing menjadi 67 persen pada sektor jasa distribusi Indonesia.

\section{DAFTAR PUSTAKA}

Abbes, S. M., B. Mostéfaa, G. M. Seghir, dan G. Y. Zakarya. 2015. Causal Interactions between FDI, and Economic Growth: Evidence from Dynamic Panel CoIntegration. Procedia Economics and Finance 23: 276-290.

Aitken, B. J. dan A. E. Harrison. 1999. Do Domestic Firms Benefit from Direct Foreign Investment? Evidence from Venezuela. The American Economic Review 89(3): 605-617.

Alhayat. A. P. dan A. Muslim. 2016. Proyeksi Ekspor dan Impor Indonesia: Suatu Pendekatan Vector Autoregressive. Buletin Ilmiah Litbang Perdagangan 10(1): 87-102. 
Almfraji, M. A dan M. K. Almsafir. 2013. Foreign Direct Investment and Economic Growth Literature Review from 1994 to 2012. Procedia-Social and Behavioral Sciences 129: 206-213.

Badan Koordinasi Penanaman Modal. 2015. Portal National Single Window for Investment. https://nswi.bkpm.go.id/ tentang_nswi Diakses tanggal 20 Oktober 2014.

Ball, D., M. Geringer, M. Minor, dan J. McNeet. 2012. International Business: The Challenge of Global Competition. The McGraw Hill Companies. New York.

Bayar, Y. 2014. Effects of Foreign Direct Investment Inflows and Domestic Investment on Economic Growth: Evidence from Turkey. International Journal of Economics and Finance 6(4): 69-78.

Beritasatu. 2012. CT Bangga Akuisisi Carrefour dari Perusahaan Perancis. http://www.beritasatu.com/bisnis/83981-ctbangga-akuisisi-carrefour-dari-perusahaanperancis.html. Diakses 26 Feruari 2018.

Chin, V., M. Meyer, E. Tan, dan B. Waltermann. 2014. Winning in ASEAN How Companies Are Preparing for Economic Integration. Part of the Winning with Growth series: 2-17.

CIA factbook. 2015. World Factbook: Where Applicable, all of the "Constitution" Entries were Recently Updated throughout the Factbook. https://www.cia.gov/ library/publications/the-world-factbook/geos /id.html. Diakses 1 Desember 2016.

Detikfinance. 2011. Chairul Tanjung Kuasai $100 \%$ Saham Carrefour Indonesia. http://finance.detik.com/berita-ekonomibisnis/2095793/chairul-tanjung-kuasai100-saham-carrefour-indonesia. Diakses 26 Februari 2018.

Ditimi, A. dan O. Matthew. 2014. FDI, Private Investment and Public Investment in Nigeria: An Unravelled Dynamic Relation. Journal of Business $\mathcal{E}$ Economic Policy 1(2): 29-38.

Ekananda, M. 2016. Analisis Ekonometrika Time Series. Mitra Wacana Media. Jakarta.
Fawaiq. M. 2015. Analisis Moda Entri Penyedia Jasa Ritel Indonesia Ke ASEAN: Studi Kasus Pada Alfamart. Buletin Ilmiah Litbang Perdagangan. 9(1): 25-43.

Fawaiq. M. 2016. Hubungan antara Consumption Abroad (Moda 2) dengan Commercial Presence (Moda 3) di Sektor Jasa Pariwisata Indonesia. Buletin Ilmiah Litbang Perdagangan. 10(1): 45-61.

Fawaiq, M. 2017. Liberalisasi Jasa Telekomunikasi Indonesia, Masuknya FDI, dan Penyerapan Tenaga Kerja Domestik. Kajian Ekonomi Keuangan 1(2): 181195.

Farrell, R. 2008. Japanese Investment in the World Economy: A Study of Strategic Themes in the Internationalisation of Japanese Industry. Edward Elgar Publishing Limited.United Kingdom.

Findly. C. dan M. Pangestu. 2016. The Services Sector as a Driver of Change: Indonesia's Experience in The ASEAN Context. Buletin of Indonesian Economic Studies 52(1):27-53.

Hill. R. C., W. E. Grififfiths, dan G. C. Lim. 2012. Principles of Econometrics. Fourth Edition. John Wiley and Sons. New York.

Ishido. H. 2012. Liberalization of Trade in Services under ASEAN n FTAs: A Mapping Exercise. Journal of East Asian Economic Integration 16(2): 155-204.

Kastrati, S. K. 2013. The Effects of Foreign Direct Investments for Host Country's Economy. European Journal of Interdisciplinary Studies 5(1): 26-38.

Latip. D. 2009. Analisa Pengaruh Penanaman Modal Asing Langsung (FDI) Terhadap Pertumbuhan Ekonomi Regional Propinsi Tahun 2000-2006. Tesis. Program Pascasarjana Ilmu Ekonomi FEUI. Depok.

Lean, H. H. dan B. W. Tan. 2011. Linkages between Foreign Direct Investment, Domestic Investment and Economic Growth in Malaysia. Journal of Economic Cooperation and Development 32(4): 75-96. 
Manning. C. dan H. Aswicahyono. 2012. Trade and Employment in Services: The Case of Indonesia. International Labour Organization. Jakarta.

Negrescu, D. dan G. Truica. 2006. Can Eu's Enhanced Co-Operation Mechanism Provide Solutions to The "Single Undertaking" Problems of The WTO?. Romanian Journal of European Affairs 6(2): 5-23.

Pedroni. P. 1999. Critical Values for Cointegration Tests in Heterogeneous Panels with Multiple Regressors. Oxford Bulletin of Economics and Statistics 61(S1): 653670.

Peraturan Presiden Republik Indonesia Nomor 44 Tahun 2016 Tentang Daftar Bidang Usaha Tertutup dan Bidang Usaha Terbuka dengan Persyaratan di Bidang Penanaman Modal. 2016. Jakarta.

Ridhwan, M. M., G. Wicaksono, L. Nurliana, P. Bary, F. T. Suryani, dan R. Satyanugroho. 2015. Analisis Daya Saing dan Strategi Industri Nasional Di Era Masyarakat Ekonomi Asean dan Perdagangan Bebas. Working Paper. Bank Indonesia.

Safitriani. S. 2014. Perdagangan Internasional dan Foreign Direct Investment (FDI) di Indonesia. Buletein Ilmiah Litbang Perdagangan 8(1): 93-116.
Samimi. A. J., S. Sadeghi, dan S. Sadeghi. 2013. The Relationship between Foreign Direct Investment and Tourism Development: Evidence from Developing Countries. Institutions and Economies 5(2): 59-68.

Shah, M. H. dan Y. Khan. 2016. Trade Liberalisation and FDI Inflows in Emerging Economies. Business \& Economic Review 8(1): 35-52.

Shawa, M. J., G. Amoro, dan Yaoshen. 2015. The Causal Link between Foreign Direct Investment, GDP Growth, Domestic Investment and Export for Kenya: the New Evidence. Journal of Economics and Sustainable Development 5(16): 107-114.

World Trade Organization (WTO). 1991. Services Sectoral Classification List (MTN. GNS/W/120). (Geneva: WTO Secretariat): 1-7.

World Trade Organization (WTO). 2001. Guidelines for The Scheduling Of Specific Commitments Under The General Agreement On Trade In Services (Document S/L/92). Geneva: WTO Secretariat.

World Trade Organization (WTO). 2002. The Legal Texts of Multilateral Trade Negotiations. (Geneva: WTO Secretariat): 284287.

World Trade Organization (WTO). 1991. Services Sectoral Classification List. (Geneva: WTO Secretariat): 1-7. 